Article

\title{
Insights on the Extraction Performance of Alkanediols and Glycerol: Using Juglans regia L. Leaves as a Source of Bioactive Compounds
}

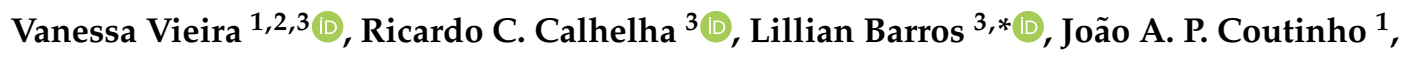 \\ Isabel C. F. R. Ferreira ${ }^{3}($ D) and Olga Ferreira $2,3, *(D)$ \\ 1 CICECO-Aveiro Institute of Materials, Complexo de Laboratórios Tecnológicos, Aveiro University, Campus \\ Universitário de Santiago, 3810-193 Aveiro, Portugal; vanessa.vieira@ua.pt (V.V.); jcoutinho@ua.pt (J.A.P.C.) \\ 2 Laboratory of Separation and Reaction Engineering-Laboratory of Catalysis and Materials (LSRE-LCM), \\ Polytechnic Institute of Bragança, Campus de Santa Apolónia, 5300-253 Bragança, Portugal \\ 3 Centro de Investigação de Montanha (CIMO), Instituto Politécnico de Bragança, Campus de Santa Apolónia, \\ 5300-253 Bragança, Portugal; calhelha@ipb.pt (R.C.C.); iferreira@ipb.pt (I.C.F.R.F.) \\ * Correspondence: lillian@ipb.pt (L.B.); oferreira@ipb.pt (O.F.); Tel.: +351-273-330901 (L.B.); \\ Tel.: +351-273-303087 (O.F.)
}

Received: 29 April 2020; Accepted: 24 May 2020; Published: 27 May 2020

\begin{abstract}
Glycerol and alkanediols are being studied as alternative solvents to extract phytochemicals from plant material, often as hydrogen bond donors in deep eutectic solvents (DESs). Many of those alcohols are liquid at room temperature, yet studies of their use as extraction solvents are scarce. In this work, glycerol and a series of alkanediols (1,2-ethanediol, 1,2-propanediol, 1,3-propanediol, 1,3-butanediol, 1,2-pentanediol, 1,5-pentanediol, and 1,2-hexanediol) were studied for the extraction of phenolic compounds from Juglans regia L. leaves, a rich source of this class of bioactive compounds. The extraction yield was quantified, and the bioactivity of both extracts and pure solvents was evaluated by measuring the anti-inflammatory and cytotoxic activities. The solvents showing the best combined results were 1,2 and 1,3-propanediol, as their extracts presented a high amount of phenolic compounds, close to the results of ethanol, and similar cytotoxicity against cervical carcinoma cells, with no impact on non-tumor porcine liver cells in the studied concentration range. On the other hand, none of the extracts (and solvents) presented anti-inflammatory activity. Overall, the results obtained in this work contribute to the study of alternative solvents that could potentially be used also as formulation media, highlighting the importance of walnut leaves as a source of bioactive compounds.
\end{abstract}

Keywords: alkanediols; glycerol; phenolic compounds; Juglans regia L.; cytotoxicity; anti-inflammatory activity; solvents

\section{Introduction}

Plants are important sources of bioactive phytochemicals, with a wide range of applications in the food, pharmaceutical, and cosmetic sectors as natural ingredients, e.g., replacing synthetic additives or improving the quality of a final product [1]. In particular, the leaves of Juglans regia L. (walnut tree) have been reported as a rich source of phenolic compounds, especially hydroxycinnamic acids and flavonols [2,3], with potential application in cosmetics or pharmaceutics [4], and stand out for their bioactive properties (antioxidant, anti-inflammatory, antidiabetic, anti-proliferative, and antibacterial, among others) $[5,6]$.

Plant extracts are frequently obtained by extraction processes using conventional volatile organic solvents. However, alternative solvents that are more efficient, sustainable, and safer are being proposed in the literature, and those include deep eutectic solvents (DES) [7,8]. While the definition 
of a deep eutectic solvent is still under debate [9], a considerable number of those solvents include components that are liquid at room temperature, such as glycerol, ethylene glycol, propanediols ( 1,2 and 1,3 isomers), butanediols (1,2,1,3 and 1,4 isomers), and triethylene glycol, as recently reviewed [10-15]. Nevertheless, their application as pure solvents remains scarce. In fact, the use of alternative alcohols as solvents to extract phytochemicals from plants is limited to a few studies using ethylene glycol, propanediols, and glycerol. As can be seen in Table 1, the solvents most commonly applied, often mixed with water, were 1,2-propanediol [16-25] and glycerol [16,25-30], and less frequently ethylene glycol [31].

In the case of systems containing glycerol, higher total phenolic contents were obtained, using small amounts of glycerol in water, from Olea europaea leaves $(9.3 \%, w / v)$ [28], Hypericum perforatum dried aerial parts $(10 \%, w / v)$ [26], and Oryza sativa bran $(20 \%, v / v)$ [30]. On the other hand, an increasing concentration of glycerol (10-90\%, w/v) leads to extracts of two Artemisia species with higher total phenolic content [27]. Philippi et al. [29] compared the extraction yields of aqueous solutions of glycerol or ethanol, obtaining similar total phenolic contents in the extracts of Solanum melongena. Regarding the use of propylene glycol, in some cases, higher extraction yields were obtained than by using water and/or ethanol. That was the case of the extracts obtained from Stevia rebaudiana leaves [22], Terminalia chebula fruits [23], Malus sylvestris wild fruit [18], and Pandanus amaryllifolius leaves [20]. On the other hand, the aqueous propylene glycol extract of Terminalia chebula fruits contained lower amounts of gallic and ellagic acids compared to the hydroethanolic extract [24]. Finally, using aqueous solutions of ethylene glycol, a higher total phenolic content was obtained from Morus alba L. when compared to acetone + (water or methanol) mixtures [31].

Besides the aqueous solutions of alcohols, other combinations were also studied. Binary mixtures of ethanol + propylene glycol or glycerol were more effective than ethanol for the extraction of rosmarinic acid, carvacrol, oleanolic acid, and ursolic acid from three Origanun species by heat-assisted extractions (HAEs) [16], while higher amounts of isorhamnetin-3-O-rutinoside were extracted from Calendula officinalis $\mathrm{L}$. flowers using an ethanol + propylene glycol + water equimolar mixture than using pure solvents or binary mixtures [17].

In this work, aqueous solutions of glycerol and alkanediols (1,2-ethanediol, 1,2-propanediol, 1,3-propanediol, 1,3-butanediol, 1,2-pentanediol, 1,5-pentanediol, and 1,2-hexanediol) were studied to extract phenolic compounds from walnut leaves. These compounds were chosen not only to evaluate the effect of increasing the alkyl chain of the diols on the extraction yield, but also considering their potential application in different areas such as pharmaceuticals or cosmetics. Some of these compounds and their functions are included in a list of cosmetic ingredients (other than perfume and aromatic raw materials) [32]: ethanol (solvent), 1,2-ethanediol (solvent/viscosity controlling/humectant), 1,2-propanediol (humectant/solvent/skin conditioning/viscosity controlling), 1,3-butanediol (humectant/solvent), and glycerol (denaturant/humectant/solvent). A recent patent published by Lavaud et al. [25] about the use of alternative solvents for food and cosmetic applications also includes 1,2-ethanediol, 1,2-propanediol, 1,3-propanediol, 1,2-pentanediol, and glycerol, highlighting these ingredients as "bio-sourced natural compounds" and the possibility of obtaining them from renewable sources. Finally, 1,5-pentanediol was also studied as a preserving and humectant ingredient for dermatological care products [33-35], and 1,2-hexanediol was proposed as a potential component for the preparation of topical formulations aiming to retard the percutaneous absorption of active pharmaceutical ingredients [36]. On an industrial scale, the use of alkanediols and glycerol could be also safer as they have lower vapor pressures compared to conventional organic solvents [37-39]. In addition, if the solvent could be part of the final formulation, the number of unit operations of the global process would be reduced by eliminating the need to separate the extracted compounds from the solvent [15,37]. Finally, to support the development of new applications, besides determining the extraction yield of the main phenolic compounds, the anti-inflammatory and cytotoxic activities of both extracts and pure solvents were also evaluated. 
Table 1. Overview of the use of glycerol and alkanediols for the extraction of phenolic compounds from plant material.

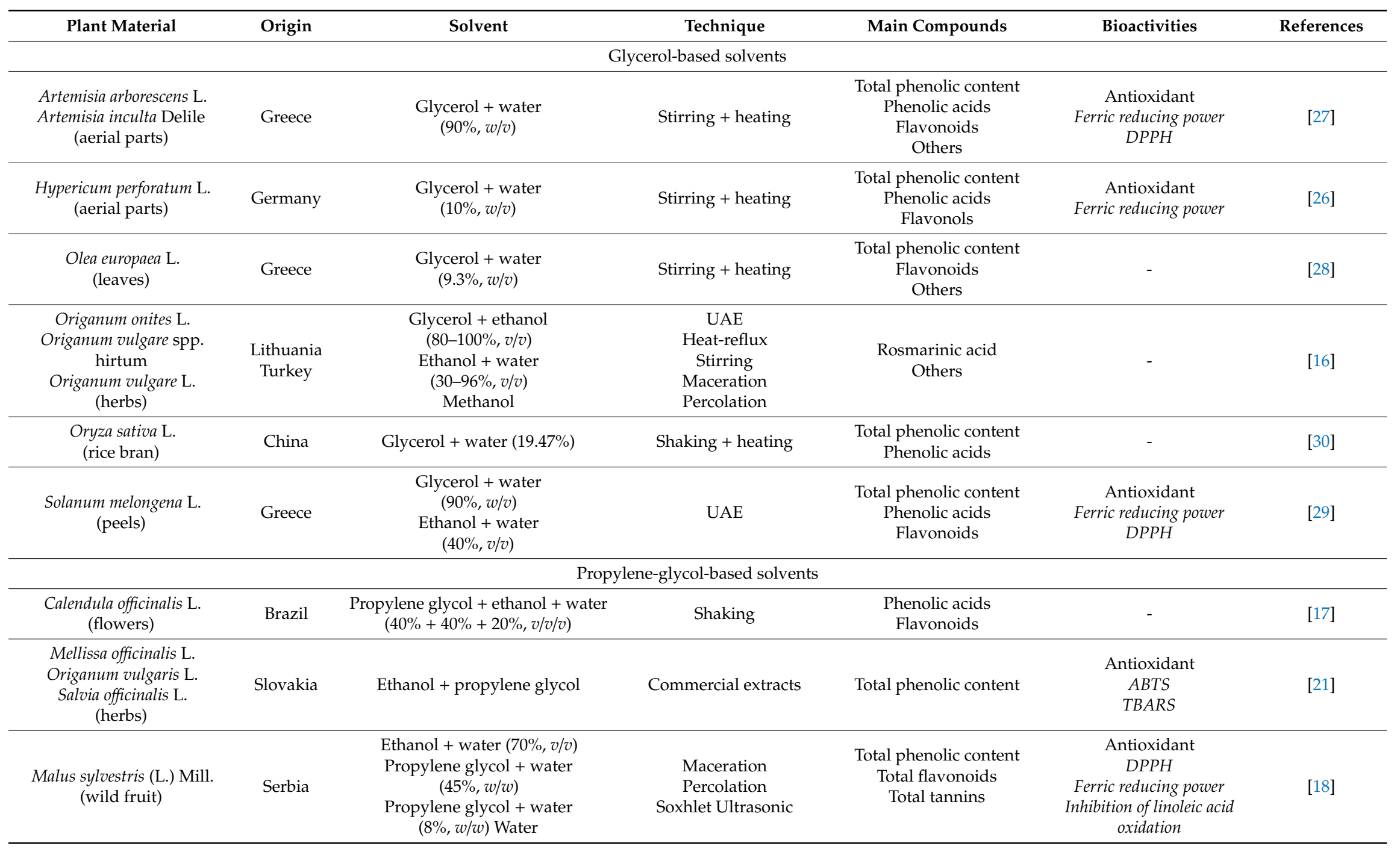


Table 1. Cont.

\begin{tabular}{|c|c|c|c|c|c|c|}
\hline Plant Material & Origin & Solvent & Technique & Main Compounds & Bioactivities & References \\
\hline \multicolumn{7}{|c|}{ Propylene-glycol-based solvents } \\
\hline $\begin{array}{l}\text { Origanum onites } \mathrm{L} . \\
\text { Origanum vulgare spp. } \\
\text { hirtum } \\
\text { Origanum vulgare } \mathrm{L} . \\
\text { (herbs) }\end{array}$ & $\begin{array}{l}\text { Lithuania } \\
\text { Turkey }\end{array}$ & $\begin{array}{l}\text { Propylene glycol + ethanol } \\
(70-90 \%, v / v) \\
\text { Ethanol + water } \\
(30-96 \%, v / v) \\
\text { Methanol }\end{array}$ & $\begin{array}{l}\text { UAE } \\
\text { Heat-reflux } \\
\text { Stirring } \\
\text { Maceration } \\
\text { Percolation }\end{array}$ & Rosmarinic acidOthers & - & [16] \\
\hline $\begin{array}{l}\text { Pandanus amaryllifolius } \\
\text { Roxb. } \\
\text { (leaf and root) }\end{array}$ & Thailand & $\begin{array}{c}\text { Propylene glycol } \\
\text { Ethanol }(95 \%) \\
\text { Propylene glycol }+ \\
\text { ethanol }(1: 4 \text { and } 1: 1, v / v)\end{array}$ & Maceration & Total phenolic content & $\begin{array}{c}\text { Antioxidant } \\
\text { DPPH } \\
\text { Linoleic acid } \\
\text { emulsion-thiocyanate } \\
\text { method }\end{array}$ & [20] \\
\hline $\begin{array}{l}\text { Stevia rebaudiana Bert. } \\
\text { (leaf) }\end{array}$ & Poland & $\begin{array}{c}\text { Propylene glycol + water (4:1) } \\
\text { Ethanol }(96 \%)\end{array}$ & Stirring & $\begin{array}{l}\text { Total phenolic content } \\
\text { Phenolic acids } \\
\text { Flavonoids }\end{array}$ & $\begin{array}{c}\text { Antioxidant } \\
\text { DPPH } \\
\text { ABTS } \\
\text { Ferric reducing power } \\
\text { Cytotoxicity } \\
\text { CRL-2522 }\end{array}$ & [22] \\
\hline $\begin{array}{l}\text { Terminalia chebula Retz } \\
\quad \text { (dried fruits) }\end{array}$ & Thailand & $\begin{array}{c}\text { Ethanol + water }(76.4 \%, v / v) 1 \\
\text { Propylene glycol + water }(36 \%, v / v)\end{array}$ & Reflux & $\begin{array}{c}\text { Total phenolic content } \\
\text { Gallic acid } \\
\text { Ellagic acid }\end{array}$ & $\begin{array}{l}\text { Antioxidant } \\
\quad \text { ABTS }\end{array}$ & [24] \\
\hline $\begin{array}{l}\text { Terminalia cheubula Retz } \\
\text { (fruits) }\end{array}$ & Thailand & $\begin{array}{c}\text { Ethanol + water }(30 \%, 50 \%, 70 \%, \\
\text { and } 100 \%) \\
\text { Propylene glycol + water } \\
(30 \%, 50 \%, 70 \% \text {, and } 100 \%)\end{array}$ & Maceration & Total phenolic content & $\begin{array}{c}\text { Antioxidant } \\
\text { DPPH } \\
\text { H2O2 inhibition } \\
\text { AAPH-induced haemolysis } \\
\text { ABTS } \\
\text { Photochemiluminescence }\end{array}$ & [23] \\
\hline $\begin{array}{l}\text { Vitis vinifera } \mathrm{L} \text {. } \\
\text { (pomace) }\end{array}$ & Italy & $\begin{array}{c}\text { Propylene glycol + ethanol (1:1 } \\
\text { and 1:3, } \\
v / v) \\
\end{array}$ & Stirring & $\begin{array}{l}\text { Total phenolic content } \\
\text { Gallic acid } \\
\text { Flavonoids }\end{array}$ & $\begin{array}{c}\text { Antioxidant } \\
D P P H \\
\text { AAPH-induced haemolysis }\end{array}$ & [19] \\
\hline \multicolumn{7}{|c|}{ Ethylene glycol-based solvents } \\
\hline $\begin{array}{l}\text { Morus alba } \mathrm{L} . \\
\quad \text { (leaf) }\end{array}$ & Korea & $\begin{array}{c}\text { Ethylene glycol + water }(25 \%, 42 \%, \\
\text { and } 58 \%) \\
\text { Acetone + water }(47 \% \text { and } 57 \%) \\
\text { Acetone + methanol }(27 \%)\end{array}$ & Heat extraction & Total phenolic content & $\begin{array}{l}\text { Antioxidant } \\
\text { DPPH }\end{array}$ & [31] \\
\hline
\end{tabular}

UAE: ultrasound-assisted extraction; DPPH: 2,2-diphenyl-1-picrylhydrazyl; ABTS: 2,2'-azino-bis-3-ethylbenzthiazoline-6-sulphonic acid; TBARS: thiobarbituric acid reactive substances;

CRL-2522: human skin fibroblasts BJ; AAPH: 2,2'-Azobis(2-amidinopropane) dihydrochloride. 


\section{Results and Discussion}

\subsection{Extraction Yields}

Aqueous solutions of glycerol and several diols (1,2-ethanediol, 1,2-propanediol, 1,3-propanediol, 1,3-butanediol, 1,2-pentanediol, 1,5-pentanediol, and 1,2-hexanediol) containing 20\% water ( $w / w)$ were used to extract phenolic compounds from J. regia L. leaves. Water and ethanol + water (80:20, w/w) solvents were also studied for comparison purposes. To carry out this study, aqueous solutions of the solvents referred to were preferred as they have shown to improve the extraction yields by reducing the solvent viscosity, enhancing the mass-transfer from the plant to the solvent media and reducing energy consumption [40]. The optimum amount of water depends on several factors such as the plant matrix or the target molecules to be extracted, as summarized in Table 1. In this work, this amount was selected taking into account a previous study aimed at solvent screening for the extraction of phenolics from the same plant material [41].

To evaluate the extraction efficiency, the amount of the four main phenolic compounds (3-O-caffeoylquinic acid, trans 3-p-coumaroylquinic acid, quercetin-3-O-glucoside and quercetin-O-pentoside) was quantified by high-performance liquid chromatography with diode-array detection (HPLC-DAD).

The extraction yields of the main phenolic compounds is presented in Table 2. As can be seen, hydroalcoholic solvents (except 1,2-hexanediol) exhibited higher extraction yields than water. This group of diols performed similarly to ethanol $(27.8 \pm 0.1 \mathrm{mg} / \mathrm{g}$ dry plant), the phenolic content ranging from $23.9 \pm 0.3 \mathrm{mg} / \mathrm{g}$ dry plant $(1,3$-butanediol) to $30.5 \pm 0.2 \mathrm{mg} / \mathrm{g}$ dry plant (1,2-ethanediol). The 1,2-ethanediol extract was the only one exceeding the extraction yields obtained by the reference solvent (ethanol). Propanediol extracts (1,2 and 1,3 isomers) have equivalent extraction yields. In contrast, with the more polar glycerol (1,2,3-propanetriol), only a total content of $18.3 \pm 0.4 \mathrm{mg} / \mathrm{g}$ dry plant was obtained. Regarding the general phenolic profile of pentanediol extracts, the 1,2 isomer extracted the highest amount of quercetin derivatives ( $24.5 \mathrm{mg} / \mathrm{g}$ dry plant), considering all solvents. In contrast, the 1,5-pentanediol liquid extract was richer in phenolic acids (5.69 mg/g dry plant) than the 1,2 isomer (1.60 mg/g dry plant). Finally, 1,2-hexanediol was the poorest solvent $(5.73 \pm 0.09 \mathrm{mg} / \mathrm{g}$ dry plant), with lower extraction yields than water $(14.1 \pm 0.3 \mathrm{mg} / \mathrm{g} \mathrm{dry} \mathrm{plant})$.

The individual amounts of each phenolic compound obtained in this work, using conventional ethanol/water (80:20, w/w) mixtures, are generally in good agreement with the ones reported in the literature, as recently reviewed [42]. In previous studies, similar amounts of 3-O-caffeoylquinic acid were found using water as solvent, and also of quercetin 3-O-glucoside and quercetin $O$-pentoside using water and ethanol [43], or even eutectic mixtures based on choline chloride and carboxylic acids [41]. On the other hand, the values found in this work were higher than the ones presented by Zhao et al. [44], Amaral et al. [45], and Santos et al. [3], while Pereira et al. [46] reported higher amounts of 3-O-caffeoylquinic acid (12.06-14.82 mg/g dw), 3-p-coumaroylquinic acid (4.69-5.99 mg/g dw), and quercetin 3-O-galactoside $(15.72-21.68 \mathrm{mg} / \mathrm{g} \mathrm{dw})$ in the aqueous (decoction) extract of different cultivars of walnut leaves. These differences arise from the combination of several factors, namely: (i) the type of solvent; (ii) extraction conditions; (iii) the plant (e.g., geographical location, time of collection, type of cultivar, etc.) $[47,48]$. In this work, the extraction conditions and the lot of the plant were the same, to allow the evaluation of the effect of changing the solvent, as discussed in the previous paragraph. 
Table 2. Quantification of the main phenolic compounds present in different extracts of $J$. regia leaves (mean \pm SD): 3-O-caffeoylquinic acid, trans 3- $p$-coumaroylquinic acid, quercetin 3-O-glucoside, quercetin O-pentoside, and total HPLC content.

\begin{tabular}{|c|c|c|c|c|c|}
\hline \multirow{2}{*}{ Solvent } & 3-O-Caffeoylquinic Acid & trans 3-p-Coumaroylquinic Acid & Quercetin 3-O-glucoside & Quercetin $O$-pentoside & Total HPLC \\
\hline & (mg/g Dry Plant) & (mg/g Dry Plant) & (mg/g Dry Plant) & (mg/g Dry Plant) & (mg/g Dry Plant) \\
\hline water & $5.16 \pm 0.06 b$ & $1.07 \pm 0.03 \mathrm{~d}$ & $4.3 \pm 0.2 \mathrm{~h}$ & $3.59 \pm 0.07 h$ & $14.1 \pm 0.3 \mathrm{~g}$ \\
\hline ethanol & $4.52 \pm 0.01 \mathrm{~d}$ & $1.23 \pm 0.02 b$ & $11.7 \pm 0.1 \mathrm{c}$ & $10.32 \pm 0.06 c$ & $27.8 \pm 0.1 \mathrm{~b}$ \\
\hline 1,2-ethanediol & $5.79 \pm 0.08 a$ & $1.36 \pm 0.02 a$ & $12.6 \pm 0.1 b$ & $10.73 \pm 0.08 b$ & $30.5 \pm 0.2 a$ \\
\hline 1,2-propanediol & $4.96 \pm 0.06 c$ & $1.14 \pm 0.01 c$ & $11.3 \pm 0.2 \mathrm{~d}$ & $9.8 \pm 0.2 \mathrm{~d}$ & $27.2 \pm 0.4 \mathrm{c}$ \\
\hline 1,3-propanediol & $5.30 \pm 0.04 b$ & $1.22 \pm 0.04 b$ & $11.1 \pm 0.1 \mathrm{~d}$ & $9.6 \pm 0.07 \mathrm{de}$ & $27.3 \pm 0.3 c$ \\
\hline 1,3-butanediol & $4.46 \pm 0.01 \mathrm{~d}$ & $1.03 \pm 0.01 \mathrm{~d}$ & $9.85 \pm 0.2 f$ & $8.6 \pm 0.2 f$ & $23.9 \pm 0.3 \mathrm{e}$ \\
\hline 1,2-pentanediol & $1.30 \pm 0.02 \mathrm{~g}$ & $0.300 \pm 0.002 \mathrm{~g}$ & $13.0 \pm 0.3 \mathrm{a}$ & $11.45 \pm 0.2 \mathrm{a}$ & $26.0 \pm 0.5 \mathrm{~d}$ \\
\hline 1,5-pentanediol & $4.47 \pm 0.07 \mathrm{~d}$ & $1.22 \pm 0.01 b$ & $10.75 \pm 0.2 \mathrm{e}$ & $9.5 \pm 0.1 \mathrm{e}$ & $25.9 \pm 0.4 \mathrm{~d}$ \\
\hline 1,2-hexanediol & $3.00 \pm 0.05 f$ & $0.8 \pm 0.03 f$ & $1.93 \pm 0.04 \mathrm{i}$ & nd & $5.73 \pm 0.09 h$ \\
\hline glycerol & $4.3 \pm 0.1 \mathrm{e}$ & $0.94 \pm 0.04 \mathrm{e}$ & $6.98 \pm 0.2 \mathrm{~g}$ & $6.1 \pm 0.1 \mathrm{~g}$ & $18.3 \pm 0.4 \mathrm{f}$ \\
\hline
\end{tabular}

Calibration curves: 3-O-caffeoylquinic acid: 5-O-caffeoylquinic acid (y = 118879x-181046; $r^{2}=0.9992$; limit of detection (LOD) = 0.20 $\mu \mathrm{g} / \mathrm{mL} ;$ limit of quantitation (LOQ) $=0.68 \mu \mathrm{g} / \mathrm{mL}$ ); trans 3-p-coumaroylquinic acid: $p$-coumaric acid $\left(\mathrm{y}=120011 \mathrm{x}+1 \times 10^{6} ; r^{2}=0.9973 ; \mathrm{LOD}=0.68 \mu \mathrm{g} / \mathrm{mL} ; \mathrm{LOQ}=1.61 \mu \mathrm{g} / \mathrm{mL}\right)$; quercetin 3-O-glucoside and quercetin $O$-pentoside: quercetin 3-O-glucoside $\left(\mathrm{y}=98385 \mathrm{x}+143369 ; r^{2}=0.9978 ; \mathrm{LOD}=0.21 \mu \mathrm{g} / \mathrm{mL} ; \mathrm{LOQ}=0.71 \mu \mathrm{g} / \mathrm{mL}\right)$. nd.: not detected. Different letters represent significant differences $(p<0.05)$. 


\subsection{Cytotoxic and Anti-Inflammatory Activities}

To assist the identification of potential applications for these extracts, cytotoxicity assays were applied not only to the extracts, but also to the solvents. The cytotoxicity was evaluated using a human tumor cell line (HeLa) and the non-tumor porcine live primary cell culture (PLP2). The HeLa cell line represents a suitable in vitro model to study cytotoxicity that has already been applied to new solvents [49] such as DES [50,51] and ionic liquids prepared from biomaterials [52]. On the other hand, PLP2 cells can be used to evaluate one specific type of cytotoxicity-hepatotoxicity [53]. Therefore, the potential toxicity occurring during/after metabolization is here represented by the porcine liver primary cells [54]. The results of the cytotoxicity assays are summarized in Table 3.

Table 3. Bioactive properties of J. regia leaves. Cytotoxicity in human tumor cell lines HeLa and non-tumor liver primary cells PLP2 ( $\left.\mathrm{GI}_{50}\right)$. Quantification for extracts and solvents (mean $\pm \mathrm{SD}$ ).

\begin{tabular}{ccccc}
\hline \multirow{2}{*}{ Solvent } & \multicolumn{2}{c}{ HeLa } & \multicolumn{2}{c}{ PLP2 } \\
\cline { 2 - 5 } & Extract $(\mu \mathrm{g} / \mathrm{mL})$ & Solvent $(\%, \boldsymbol{v} / \boldsymbol{v})$ & Extract $(\mu \mathrm{g} / \mathrm{mL})$ & Solvent $(\%, \boldsymbol{v} / \boldsymbol{v})$ \\
\hline Water & $>500$ & $>4$ & $>500$ & $>4$ \\
Ethanol & $245 \pm 14 \mathrm{~b}$ & $>4$ & $>500$ & $>4$ \\
1,2-ethanediol & $97 \pm 10 \mathrm{e}$ & $>4$ & $142 \pm 5 \mathrm{~b}$ & $>4$ \\
1,2-propanediol & $292 \pm 24 \mathrm{a}$ & $>4$ & $>500$ & $>4$ \\
1,3-propanediol & $216 \pm 10 \mathrm{c}$ & $>4$ & $>500$ & $>4$ \\
1,3-butanediol & $257 \pm 12 \mathrm{~b}$ & $>4$ & $>500$ & $>4$ \\
1,2-pentanediol & $151 \pm 12 \mathrm{~d}$ & $0.63 \pm 0.04 \mathrm{a}$ & $232 \pm 13 \mathrm{a}$ & $0.89 \pm 0.04 \mathrm{a}$ \\
1,5-pentanediol & $212 \pm 4 \mathrm{c}$ & $0.49 \pm 0.02 \mathrm{~b}$ & $141 \pm 3 \mathrm{~b}$ & $0.59 \pm 0.02 \mathrm{~b}$ \\
1,2-hexanediol & $37 \pm 2 \mathrm{f}$ & $0.36 \pm 0.02 \mathrm{c}$ & $48 \pm 5 \mathrm{~b}$ & $0.285 \pm 0.005 \mathrm{c}$ \\
Glycerol & $88 \pm 4 \mathrm{e}$ & $>4$ & $143 \pm 5 \mathrm{~b}$ & $>4$ \\
\hline
\end{tabular}

Positive controls: Ellipticine (GI ${ }_{50}$ values): HeLa: $1.03 \pm 0.09 \mu \mathrm{g} / \mathrm{mL}$; PLP2: $2.3 \pm 0.2 \mu \mathrm{g} / \mathrm{mL}$. Results expressed in mean values \pm standard deviation (SD). Different letters represent significant differences $(p<0.05)$.

It is important to mention that none of the extracts were as active as the positive control ( $\mathrm{GI}_{50}$ ellipticine $=1.0 \pm 0.1$ and $2.3 \pm 0.2 \mu \mathrm{g} / \mathrm{mL}$ for HeLa and PLP2, respectively). As can be seen, the extracts obtained using standard solvents (water and ethanol) have no toxicological impact in PLP2 cells, allowing normal cell proliferation under concentrations up to $500 \mu \mathrm{g} / \mathrm{mL}$. The same was observed for the aqueous extract applied to the HeLa cell culture; however, for the ethanolic extract, a $\mathrm{GI}_{50}$ of $245 \pm 14 \mu \mathrm{g} / \mathrm{mL}$ was obtained. Regarding the extracts showing cytotoxic potential only against the tumor cell line but not the non-tumor one (1,2- and 1,3-propanediol, and 1,3-butanediol), 1,3-propanediol was the most effective solvent $\left(\mathrm{GI}_{50}=216 \pm 10 \mu \mathrm{g} / \mathrm{mL}\right.$ and $>500 \mu \mathrm{g} / \mathrm{mL}$, respectively, for the HeLa and PLP2 cell cultures). Interestingly, the extracts obtained using 1,2-ethanediol and glycerol showed toxicity against the selected control cell culture (PLP2), with $\mathrm{GI}_{50}$ values of $142 \pm 5 \mu \mathrm{g} / \mathrm{mL}$ and $143 \pm 5 \mu \mathrm{g} / \mathrm{mL}$, respectively. Nevertheless, the pure solvents (without extracts) were absent of cytotoxicity up to concentrations of $4 \%$. Besides the cytotoxicity of 1,2-ethanediol and glycerol extracts against the PLP2 cells, the $\mathrm{GI}_{50}$ values for the HeLa cells were lower $\left(\mathrm{GI}_{50}=97 \pm 10 \mu \mathrm{g} / \mathrm{mL}\right.$ and $88 \pm 4 \mu \mathrm{g} / \mathrm{mL}$, respectively); thus, the extracts were more active against the cervical human tumor cell line. Finally, the most cytotoxic extract was obtained with 1,2-hexanediol, the concentrations of extract being significantly lower than those obtained with the remaining solvents $\left(\mathrm{GI}_{50, \mathrm{HeLa}}=37 \pm 2 \mu \mathrm{g} / \mathrm{mL}\right)$. The same was observed for the pure solvent, constituting a strong cytotoxic agent even when highly diluted $\left(\mathrm{GI}_{50, \mathrm{PLP} 2}=0.285 \pm 0.005 \%\right.$ and $\left.\mathrm{GI}_{50, \mathrm{HeLa}}=0.36 \pm 0.02 \%\right)$. This was also observed for both pentanediol isomers, which presented activity for concentrations lower than $1 \%$. The 1,5-pentanediol extract showed significantly higher $\mathrm{GI}_{50}$ values against the HeLa cell line $\left(\mathrm{GI}_{50}=212 \pm 4 \mu \mathrm{g} / \mathrm{mL}\right)$ than glycerol and 1,2-ethanediol extracts, but the effective $\mathrm{GI}_{50}$ for the PLP2 cells was lower $(141 \pm 3 \mu \mathrm{g} / \mathrm{mL})$, which is not desirable as ideally, $\mathrm{GI}_{50, \mathrm{PLP} 2}>\mathrm{GI}_{50, \mathrm{HeLa}}$. 
To complete this discussion, it is important to clarify the contribution of the solvent to the final toxicity of the extract. For that reason, the toxicity of the solvent was evaluated in a concentration range that includes the concentration of the solvent in the liquid extracts studied in the bioactivity studies. When both extracts and solvents presented cytotoxicity (1,2-pentanediol, 1,5-pentanediol, and 1,2-hexanediol), it was found that the concentrations providing cytotoxicity for the pure solvents are similar to those presented by the extracts ( $\mathrm{HeLa}=0.41 \%, 0.57 \%$, and $0.10 \%$; PLP2 $=0.63 \%, 0.38 \%$, and $0.13 \%$, respectively). Thus, the toxicity found is probably due to the presence of the solvent. On the other hand, for the remaining extracts, the bioactivity could be attributed to the bioactive substances in the extract since the solvents do not show toxicity against the studied cell lines up to a $4 \%$ concentration, which is higher than the amount of solvent present in the analyzed liquid extracts.

The cytotoxicity of walnut leaf extracts was previously studied by Santos et al. [3] for several cell lines, including HeLa and PLP2 cell cultures. The authors reported the absence of toxicity of extracts obtained by decoction $\left(\mathrm{GI}_{50}>400 \mu \mathrm{g} / \mathrm{mL}\right)$, a specific type of aqueous extract, which is in good agreement with our results. In contrast, the methanolic extract of the same plant material, as well as those obtained from green and yellow leaves using ethanol + water [42], inhibited the proliferation of HeLa but not PLP2 cells, which also agrees with the results obtained in the present study using conventional solvents.

The evaluation of the cytotoxicity of the liquid extracts obtained with alkanediols and glycerol has seldom been carried out (Table 1). A comparative study of the cytotoxic potential of Stevia rebaudiana leaf extracts and the selected solvents (water, ethanol, and aqueous propylene glycol) was performed by Gaweł-Bęben et al. [22] using skin fibroblast cells as a model to evaluate the extracts' potential as food and cosmetic ingredients. Generally, the extracts show higher cytotoxic potential than the solvents for the same solvent concentration. Furthermore, the aqueous ethanolic and propylene glycol extracts (between $2 \%$ and $5 \%$ ) promoted a significant decrease in the skin fibroblasts' viability. Thus, the authors concluded that the potential of those extracts for cosmetic or food formulations are dependent on further studies to establish an appropriate dose, adapted to the desired product.

Finally, in a previous study, the extracts of green leaves of $J$. regia showed anti-inflammatory activity [42]; thus, this assay was also applied here. However, neither the liquid extracts nor solvents showed anti-inflammatory potential at the studied concentration range $\left(\mathrm{EC}_{50}>500 \mu \mathrm{g} / \mathrm{mL}\right.$ or $4 \%$ solvent). To the best of our knowledge, this is the first time that this cell-based assay was applied to the selected solvents and extracts.

\section{Materials and Methods}

\subsection{Standards and Reagents}

HPLC-grade acetonitrile, 1,2-ethanediol (99.94\%), and glycerol (99.88\%) were obtained from Fisher Scientific, Waltham, MA, USA. The standards 5-O-caffeoylquinic acid, $p$-coumaric acid, and quercetin 3-O-glucoside and the solvent 1,3-butanediol (99.5\%) were purchased from Sigma-Aldrich. 1,5-pentanediol (98\%) was obtained from ACROS Organics, Morris Plains, NJ, USA. 1,3-propanediol ( $\geq 99.8 \%$ ) was supplied by DuPont \& Lyle BioProducts, Loudon, TN, USA. 1,2-pentanediol (>98\%) was purchased from TCI, Tokyo, Japan, while 1,2-hexanediol (97\%) was from Alfa AESAR, Kandel, Germany. 1,2-propanediol (99.5\%) was purchased from Panreac, Barcelona, Spain. All the other chemicals were of analytical grade and purchased from common sources.

\subsection{Plant Material}

The Juglans regia L. (walnut) dried leaves were purchased from Soria Natural, S.A., Soria, Spain. According to the distributor, the leaves were collected in Soria (Spain) during June 2014 and naturally dried in a room with controlled humidity. Before the extractions, the samples were milled (60 to 20 mesh) and stored in a desiccator protected from light for subsequent assays. 


\subsection{Extraction Methodology}

Preparation of solvents: firstly, the amount of water in the organic solvents used to prepare the different solutions was measured using a Metrohm 831 Karl Fisher coulometer, Metrohm, Herisau, Switzerland; (data not shown). For the preparation of the solvents, each component was accurately weighed $\left( \pm 10^{-4} \mathrm{~g}\right)$. Aqueous solutions of different alcohols (ethanol, glycerol, 1,2-ethanediol, 1,2-propanediol, 1,3-propanediol, 1,3-butanediol, 1,2-pentanediol, 1,5-pentanediol, and 1,2-hexanediol) were prepared containing $20 \%$ (in weight) of water.

Extraction technique: the heat-assisted extractions (HAE) were performed using heating equipment with magnetic stirring (Carousel 12 Plus Reaction Station ${ }^{\mathrm{TM}}$, Radleys Tech, Essex, UK). The powdered samples $(0.3 \mathrm{~g})$ were extracted with $10 \mathrm{~mL}$ of each solvent for $120 \mathrm{~min}$ at $50{ }^{\circ} \mathrm{C}$ and $600 \mathrm{rpm}$. These conditions were set for solvent screening, taking into consideration previous results using, as solvents, mixtures of water and ethanol [43] and aqueous mixtures of choline chloride and carboxylic acids [41]. After extraction, the mixtures were filtered through a Whatman $n^{\circ} 4$ paper type (Prat Dumas, Couze-St-Front, France) for further analysis.

\subsection{Chromatographic Analysis of the Main Phenolic Compounds}

Before chromatographic analysis, the samples of the solutions containing the extracts were diluted with water and filtered through $0.2 \mu \mathrm{m}$ disposable liquid chromatography (LC) filter disks (30 mm, regenerated cellulose; Whatman, Maidstone, UK). The samples were analyzed using a Shimadzu 20A series UFLC (Ultra-Fast Liquid Chromatograph, Shimadzu Corporation, Kyoto, Japan) with a quaternary pump and a photodiode array detector (PDA) coupled to an LC solution software data-processing station. A Waters Spherisorb S3 ODS-2 $\mathrm{C}_{18},(3 \mu \mathrm{m}, 4.6 \mathrm{~mm} \times 150 \mathrm{~mm}$; Waters Associates, PA, USA) column was used, operating at $35^{\circ} \mathrm{C}$. The chromatographic method was previously described by the authors [43]. A diode array detector (DAD) was used at 280 and $370 \mathrm{~nm}$ wavelengths. The target phenolic compounds were identified according to their UV spectra and retention time [55]. For the quantitative analysis, a baseline to valley integration with baseline projection mode was used to calculate peak areas, and external standards were used for quantification. The results were expressed in $\mathrm{mg}$ per $\mathrm{g}$ of dry plant ( $\mathrm{mg} / \mathrm{g}$ dry plant).

\subsection{Cytotoxicity}

J. regia leaf extracts $(30 \mathrm{mg} / \mathrm{mL})$ and solvents were studied regarding their inhibitory growth activity of the HeLa (cervical carcinoma) cell line and the non-tumor PLP2 cells (porcine liver primary cells) by using a sulforhodamine B assay. The extracts were diluted to obtain a stock solution of $10 \mathrm{mg} / \mathrm{mL}$, and the concentration of the working solutions ranged from 500 to $7.8 \mu \mathrm{g} / \mathrm{mL}$, while the concentration of the solvents ranged from $4 \%$ to $0.0156 \%$. Ellipticine was used as positive control. The experimental protocol related to the cell cultures was previously described by Barros et al. [55] and Abreu et al. [53]. The concentration needed to reach $50 \%$ of the growth inhibition effect $\left(\mathrm{GI}_{50}\right)$ was determined.

\subsection{Anti-Inflammatory Activity}

The walnut leaf extracts $(30 \mathrm{mg} / \mathrm{mL})$ and the pure solvents were tested with a lipopolysaccharideinduced nitric oxide (NO) production assay according to Corrêa et al. [56], using a mouse macrophage-like cell line (RAW264.7). The extracts were diluted to obtain a stock solution of $10 \mathrm{mg} / \mathrm{mL}$, and the concentration of the working solutions ranged from 500 to $7.8 \mu \mathrm{g} / \mathrm{mL}$. Again, the concentration of the solvents ranged from $4 \%$ to $0.0156 \%$. Then, the anti-inflammatory activity was assessed by measuring the nitrite concentration in the cell culture medium, using the Griess Reagent System kit. Dexamethasone was used as a positive control. The concentration providing $50 \%$ of the inhibition of $\mathrm{NO}$ production $\left(\mathrm{EC}_{50}\right)$ was determined. 


\subsection{Statistical Analysis}

In the bioactivity assays, duplicates of each extract were assayed, and three repetitions of each methodology were performed, with the results expressed as mean values and standard deviations (SD). One-way ANOVA followed by Tukey's HSD test $(p=0.05)$ were used to analyze the results. Furthermore, significant differences between two samples were established by applying a student's $t$-test, with $p=0.05$ using the IBM SPSS Statistics for Windows, Version 23.0. (IBM Corp., Armonk, New York, NY, USA).

\section{Conclusions}

Aqueous solutions of several alkanediols were able to extract similar amounts of phenolic compounds to ethanol, a conventional volatile solvent for these target compounds, ethylene glycol being the best solvent. Among alkanediols, propanediols (1,2 and 1,3 isomers) stand out if both extraction yield and bioactivity studies are considered. Their extraction efficiency was close to ethanol, and their extracts also presented similar cytotoxicity, being active against the human cervical carcinoma cell line but not against the non-tumor porcine liver primary cell culture. None of the aqueous mixtures of solvents showed anti-inflammatory activity. Regarding the studied solvents (without extracts), those having up to four carbon atoms were not toxic for the selected cell cultures in the studied concentration range.

The results obtained suggest the use of the extracts prepared in 1,2 and 1,3-propanediol as a source of important phytochemicals with bioactive properties. Depending on the envisioned application, further tests should be carried out to ensure the safety of the solvents and extracts, while optimizing the extraction conditions.

Author Contributions: Conceptualization, V.V., J.A.P.C., I.C.F.R.F., and O.F.; Methodology, V.V., L.B., and R.C.C.; Formal Analysis, V.V., L.B., and R.C.C.; Investigation, V.V. and L.B.; Data Curation, V.V.; Writing-Original Draft Preparation, V.V. and O.F.; Writing-Review \& Editing, L.B., J.A.P.C., I.C.F.R.F., and O.F.; Supervision, J.A.P.C. and O.F.; Project Administration, I.C.F.R.F. and O.F.; Funding Acquisition, I.C.F.R.F. and O.F. All authors have read and agreed to the published version of the manuscript.

Funding: This work was developed within the scope of the CIMO-Mountain Research Center UIDB/00690/2020 and CICECO-Aveiro Institute of Materials UIDB/50011/2020 \& UIDP/50011/2020 projects, both financed by national funds through the Portuguese Foundation for Science and Technology (FCT)/MCTES, as well as POCI-01-0145-FEDER-006984 (LA LSRE-LCM), funded by ERDF, through POCI-COMPETE2020 and FCT. The authors also thank the national funding from FCT, P.I., through the individual scientific employment program-contract for L. Barros and R. C. Calhelha and V. Vieira's grant (SFRH/BD/108487/2015). Support was also provided by project AllNat-POCI-01-0145-FEDER-030463 (PTDC/EQU-EPQ/30463/2017), funded by FEDER funds through COMPETE2020-Programa Operacional Competitividade e Internacionalização (POCI), and by national funds through the Foundation for Science and Technology (FCT/MCTES).

Conflicts of Interest: The authors declare no conflict of interest.

\section{References}

1. Rostagno, M.A.; Prado, J.M. Natural Product Extraction-Principles and Applications, 1st ed.; Rostagno, M.A., Prado, J.M., Eds.; The Royal Society of Green Chemistry: Cambridge, UK, 2013; ISBN 978-1-84973-606-0.

2. Gawlik-Dziki, U.; Durak, A.; Pecio, Ł.; Kowalska, I. Nutraceutical Potential of Tinctures from Fruits, Green Husks, and Leaves of Juglans regia L. Sci. World J. 2014, 2014, 1-10. [CrossRef]

3. Santos, A.; Barros, L.; Calhelha, R.C.; Dueñas, M.; Carvalho, A.M.; Santos-Buelga, C.; Ferreira, I.C.; Dueñas, M. Leaves and decoction of Juglans regia L.: Different performances regarding bioactive compounds and in vitro antioxidant and antitumor effects. Ind. Crop. Prod. 2013, 51, 430-436. [CrossRef]

4. Ribeiro, A.S.; Estanqueiro, M.; Oliveira, M.B.P.P.; Lobo, J.M.S. Main Benefits and Applicability of Plant Extracts in Skin Care Products. Cosmetics 2015, 2, 48-65. [CrossRef]

5. Panth, N.; Paudel, K.R.; Karki, R. Phytochemical profile and biological activity of Juglans regia. J. Integr. Med. 2016, 14, 359-373. [CrossRef] 
6. Jahanban-Esfahlan, A.; Ostadrahimi, A.; Tabibiazar, M.; Amarowicz, R. A Comparative Review on the Extraction, Antioxidant Content and Antioxidant Potential of Different Parts of Walnut (Juglans regia L.) Fruit and Tree. Molecules 2019, 24, 2133. [CrossRef] [PubMed]

7. Vanda, H.; Dai, Y.; Wilson, E.G.; Verpoorte, R.; Choi, Y.H. Green solvents from ionic liquids and deep eutectic solvents to natural deep eutectic solvents. C. R. Chim. 2018, 21, 628-638. [CrossRef]

8. Dai, Y.; Van Spronsen, J.; Witkamp, G.-J.; Verpoorte, R.; Choi, Y.H. Natural deep eutectic solvents as new potential media for green technology. Anal. Chim. Acta 2013, 766, 61-68. [CrossRef]

9. Martins, M.A.R.; Pinho, S.P.; Coutinho, J.A.P. Insights into the Nature of Eutectic and Deep Eutectic Mixtures. J. Solut. Chem. 2018, 48, 962-982. [CrossRef]

10. Zainal-Abidin, M.H.; Hayyan, M.; Hayyan, A.; Jayakumar, N.S. New horizons in the extraction of bioactive compounds using deep eutectic solvents: A review. Anal. Chim. Acta 2017, 979, 1-23. [CrossRef]

11. Jablonský, M.; Škulcová, A.; Malvis, A.; Šima, J. Extraction of value-added components from food industry based and agro-forest biowastes by deep eutectic solvents. J. Biotechnol. 2018, 282, 46-66. [CrossRef]

12. Huang, J.; Guo, X.; Xu, T.; Fan, L.; Zhou, X.; Wu, S. Ionic deep eutectic solvents for the extraction and separation of natural products. J. Chromatogr. A 2019, 1598, 1-19. [CrossRef] [PubMed]

13. Benvenutti, L.; Zielinski, A.A.F.; Ferreira, S.R. Which is the best food emerging solvent: IL, DES or NADES? Trends Food Sci. Technol. 2019, 90, 133-146. [CrossRef]

14. Cunha, S.C.; Fernandes, J.O. Extraction techniques with deep eutectic solvents. TrAC Trends Anal. Chem. 2018, 105, 225-239. [CrossRef]

15. Ruesgas-Ramón, M.; Figueroa-Espinoza, M.C.; Durand, E. Application of Deep Eutectic Solvents (DES) for Phenolic Compounds Extraction: Overview, Challenges, and Opportunities. J. Agric. Food Chem. 2017, 65, 3591-3601. [CrossRef]

16. Baranauskaitė, J.; Jakštas, V.; Ivanauskas, L.; Kopustinskienė, D.M.; Drakšienè, G.; Masteikova, R.; Bernatonienè, J. Optimization of carvacrol, rosmarinic, oleanolic and ursolic acid extraction from oregano herbs (Origanum onites L., Origanum vulgare spp. hirtum and Origanum vulgare L.). Nat. Prod. Res. 2016, 30, 672-674. [CrossRef] [PubMed]

17. Moraes, M.D.L.; Da Silva, H.D.T.; Blanes, L.; Doble, P.A.; Tavares, M.F.M.; Dobb, P. Optimization of chemometric approaches for the extraction of isorhamnetin-3-O-rutinoside from Calendula officinalis $\mathrm{L}$. J. Pharm. Biomed. Anal. 2016, 125, 408-414. [CrossRef] [PubMed]

18. Stojiljković, D.; Arsić, I.; Tadić, V. Extracts of wild apple fruit (Malus sylvestris (L.) Mill., Rosaceae) as a source of antioxidant substances for use in production of nutraceuticals and cosmeceuticals. Ind. Crop. Prod. 2016, 80, 165-176. [CrossRef]

19. Manconi, M.; Marongiu, F.; Manca, M.L.; Caddeo, C.; Sarais, G.; Cencetti, C.; Pucci, L.; Longo, V.; Bacchetta, G.; Fadda, A.M. Nanoincorporation of bioactive compounds from red grape pomaces: In vitro and ex vivo evaluation of antioxidant activity. Int. J. Pharm. 2017, 523, 159-166. [CrossRef]

20. Jimtaisong, A.; Krisdaphong, P. Antioxidant Activity of Pandanus amaryllifolius Leaf and Root Extract and its Application in Topical Emulsion. Trop. J. Pharm. Res. 2013, 12, 425-431. [CrossRef]

21. Lahucky, R.; Nuernberg, K.; Kovac, L.; Bucko, O.; Nuernberg, G. Assessment of the antioxidant potential of selected plant extracts-In vitro and in vivo experiments on pork. Meat Sci. 2010, 85, 779-784. [CrossRef]

22. Gaweł-Bęben, K.; Bujak, T.; Nizioł-Łukaszewska, Z.; Antosiewicz, B.; Jakubczyk, A.; Karaś, M.; Rybczyńska-Tkaczyk, K. Stevia Rebaudiana Bert. Leaf Extracts as a Multifunctional Source of Natural Antioxidants. Molecules 2015, 20, 5468-5486. [CrossRef] [PubMed]

23. Chulasiri, M.; Wanaswas, P.; Sriaum, D.; Nakamat, S.; Wongkrajang, Y.; Kongsaktrakoon, B.; Phornchirasilp, S.; Songchitsomboon, S.; Leelarungrayub, D. Utilizing hydroglycolic extract from myrobalan fruits to counteract reactive oxygen species. Int. J. Cosmet. Sci. 2011, 33, 371-376. [CrossRef] [PubMed]

24. Tubtimdee, C.; Shotipruk, A. Extraction of phenolics from Terminalia chebula Retz with water-ethanol and water-propylene glycol and sugaring-out concentration of extracts. Sep. Purif. Technol. 2011, 77, 339-346. [CrossRef]

25. Lavaud, A.; Laguerre, M.; Birtic, S.; Fabiano Tixier, A.S.; Roller, M.; Chemat, F.; Bily, A.C. Eutectic Extraction Solvents, Extraction Methods by Eutectigenesis Using Said Solvents, and Extracts Derived from Said Extraction Methods. International Publication Number WO 2016/162703, 13 October 2016. 
26. Karakashov, B.; Grigorakis, S.; Loupassaki, S.; Makris, D.P. Optimisation of polyphenol extraction from Hypericum perforatum (St. John's Wort) using aqueous glycerol and response surface methodology. J. Appl. Res. Med. Aromat. Plants 2015, 2, 1-8. [CrossRef]

27. Shehata, E.; Grigorakis, S.; Loupassaki, S.; Makris, D.P. Extraction optimisation using water/glycerol for the efficient recovery of polyphenolic antioxidants from two Artemisia species. Sep. Purif. Technol. 2015, 149, 462-469. [CrossRef]

28. Apostolakis, A.; Grigorakis, S.; Makris, D.P. Optimisation and comparative kinetics study of polyphenol extraction from olive leaves (Olea europaea) using heated water/glycerol mixtures. Sep. Purif. Technol. 2014, 128, 89-95. [CrossRef]

29. Philippi, K.; Tsamandouras, N.; Grigorakis, S.; Makris, D.P. Ultrasound-Assisted Green Extraction of Eggplant Peel (Solanum melongena) Polyphenols Using Aqueous Mixtures of Glycerol and Ethanol: Optimisation and Kinetics. Environ. Process. 2016, 3, 369-386. [CrossRef]

30. Huang, H.; Wang, Z.; Aalim, H.; Limwachiranon, J.; Li, L.; Duan, Z.; Ren, G.; Luo, Z. Green recovery of phenolic compounds from rice byproduct (rice bran) using glycerol based on viscosity, conductivity and density. Int. J. Food Sci. Technol. 2018, 54, 1363-1371. [CrossRef]

31. Kim, J.-M.; Chang, S.-M.; Kim, I.-H.; Kim, Y.E.; Hwang, J.-H.; Kim, K.-S.; Kim, W.-S. Design of optimal solvent for extraction of bio-active ingredients from mulberry leaves. Biochem. Eng. J. 2007, 37, 271-278. [CrossRef]

32. European Commission Commission Decision of 9 February 2006 amending Decision 96/335/EC establishing an inventory and a common nomenclature of ingredients employed in cosmetic products (2006/257/EC). Off. J. Eur. Union 2006, 1-528.

33. Foti, C.; Bonamonte, D.; Cassano, N.; Conserva, A.; Vena, G.A. Allergic contact dermatitis to propyl gallate and pentylene glycol in an emollient cream. Australas. J. Dermatol. 2010, 51, 147-148. [CrossRef]

34. Kerre, S. Allergic contact dermatitis to pentylene glycol in a cosmetic cream. Contact Dermat. 2008, 58, 122-123. [CrossRef] [PubMed]

35. Gallo, R.; Viflizzo, G.; Vecchio, F.; Parodi, A. Allergic contact dermatitis from pentilene glycol in an emolient cream, with possible co-sensitization to resveratrol. Contact Dermatitis 2003, 48, 176-177. [CrossRef] [PubMed]

36. Li, N.; Jia, W.; Zhang, Y.; Tan, F.; Zhang, J. Synergistic effect of 1,4-cyclohexanediol and 1,2-hexanediol on percutaneous absorption and penetration of metronidazole. Int. J. Pharm. 2011, 415, 169-174. [CrossRef] [PubMed]

37. Chemat, F.; Abert-Vian, M.; Fabiano-Tixier, A.S.; Strube, J.; Uhlenbrock, L.; Gunjevic, V.; Cravotto, G. Green extraction of natural products. Origins, current status, and future challenges. TrAC Trends Anal. Chem. 2019, 118, 248-263. [CrossRef]

38. Verevkin, S.P. Determination of vapor pressures and enthalpies of vaporization of 1,2-alkanediols. Fluid Phase Equilibria 2004, 224, 23-29. [CrossRef]

39. Mokbel, I.; Sawaya, T.; Zanota, M.-L.; Naccoul, R.A.; Jose, J.; De Bellefon, C. Vapor-Liquid Equilibria of Glycerol, 1,3-Propanediol, Glycerol + Water, and Glycerol + 1,3-Propanediol. J. Chem. Eng. Data 2012, 57, 284-289. [CrossRef]

40. Passos, H.; Freire, M.G.; Coutinho, J.A.P. Ionic liquid solutions as extractive solvents for value-added compounds from biomass. Green Chem. 2014, 16, 4786-4815. [CrossRef]

41. Vieira, V.; Prieto, M.; Barros, L.; Coutinho, J.A.; Ferreira, I.C.; Ferreira, M.O.A.S. Enhanced extraction of phenolic compounds using choline chloride based deep eutectic solvents from Juglans regia L. Ind. Crop. Prod. 2018, 115, 261-271. [CrossRef]

42. Vieira, V.; Pereira, C.; Pires, T.C.; Calhelha, R.C.; Alves, M.J.; Ferreira, M.O.A.S.; Barros, L.; Ferreira, I.C. Phenolic profile, antioxidant and antibacterial properties of Juglans regia L. (walnut) leaves from the Northeast of Portugal. Ind. Crop. Prod. 2019, 134, 347-355. [CrossRef]

43. Vieira, V.; Prieto, M.; Barros, L.; Coutinho, J.A.P.; Ferreira, M.O.A.S.; Ferreira, I.C. Optimization and comparison of maceration and microwave extraction systems for the production of phenolic compounds from Juglans regia L. for the valorization of walnut leaves. Ind. Crop. Prod. 2017, 107, 341-352. [CrossRef]

44. Zhao, M.-H.; Jiang, Z.-T.; Liu, T.; Li, R. Flavonoids in Juglans regia L. Leaves and Evaluation of In Vitro Antioxidant Activity via Intracellular and Chemical Methods. Sci. World J. 2014, 2014, 1-6. [CrossRef]

45. Amaral, J.S.; Seabra, R.; Andrade, P.B.; Valentão, P.; Pereira, J.A.; Ferreres, F. Phenolic profile in the quality control of walnut (Juglans regia L.) leaves. Food Chem. 2004, 88, 373-379. [CrossRef] 
46. Pereira, J.A.; Oliveira, I.; Sousa, A.; Valentão, P.; Andrade, P.B.; Ferreira, I.C.; Ferreres, F.; Bento, A.; Seabra, R.; Estevinho, L. Walnut (Juglans regia L.) leaves: Phenolic compounds, antibacterial activity and antioxidant potential of different cultivars. Food Chem. Toxicol. 2007, 45, 2287-2295. [CrossRef] [PubMed]

47. Sampaio, B.L.; Edrada-Ebel, R.; Da Costa, F.B. Effect of the environment on the secondary metabolic profile of Tithonia diversifolia: A model for environmental metabolomics of plants. Sci. Rep. 2016, 6, 29265. [CrossRef] [PubMed]

48. Zhang, Q.; Lin, L.; Ye, W.-C. Techniques for extraction and isolation of natural products: A comprehensive review. Chin. Med. 2018, 13, 20. [CrossRef] [PubMed]

49. Xia, X.; Wan, R.; Wang, P.; Huo, W.; Dong, H.; Du, Q. Toxicity of imidazoles ionic liquid [C16mim]Cl to Hela cells. Ecotoxicol. Environ. Saf. 2018, 162, 408-414. [CrossRef]

50. Radošević, K.; Ćurko, N.; Srček, V.G.; Bubalo, M.C.; Tomasevic, M.; Ganić, K.K.; Redovniković, I.R. Natural deep eutectic solvents as beneficial extractants for enhancement of plant extracts bioactivity. LWT 2016, 73 , 45-51. [CrossRef]

51. Hayyan, M.; Mbous, Y.P.; Looi, C.Y.; Wong, W.F.; Hayyan, A.; Salleh, M.Z.M.; Mohd-Ali, O. Natural deep eutectic solvents: Cytotoxic profile. SpringerPlus 2016, 5, 913. [CrossRef]

52. Gouveia, W.; Jorge, T.; Martins, S.; Meireles, M.; Carolino, M.; Cruz, C.; De Almeida, T.S.; Araújo, M.E.M. Toxicity of ionic liquids prepared from biomaterials. Chemosphere 2014, 104, 51-56. [CrossRef]

53. Abreu, R.; Ferreira, I.C.; Calhelha, R.C.; Lima, R.T.; Vasconcelos, M.H.; Adega, F.; Chaves, R.; Queiroz, M.J.R.P. Anti-hepatocellular carcinoma activity using human HepG2 cells and hepatotoxicity of 6-substituted methyl 3-aminothieno[3,2-b]pyridine-2-carboxylate derivatives: In vitro evaluation, cell cycle analysis and QSAR studies. Eur. J. Med. Chem. 2011, 46, 5800-5806. [CrossRef] [PubMed]

54. Rached, W.; Zeghada, F.Z.; Bennaceur, M.; Barros, L.; Calhelha, R.C.; Heleno, S.; Alves, M.; Carvalho, A.M.; Marouf, A.; Ferreira, I.C. Phytochemical analysis and assessment of antioxidant, antimicrobial, anti-inflammatory and cytotoxic properties of Tetraclinis articulata (Vahl) Masters leaves. Ind. Crop. Prod. 2018, 112, 460-466. [CrossRef]

55. Barros, L.; Pereira, E.; Calhelha, R.C.; Dueñas, M.; Carvalho, A.M.; Santos-Buelga, C.; Ferreira, I.C.; Dueñas, M. Bioactivity and chemical characterization in hydrophilic and lipophilic compounds of Chenopodium ambrosioides L.. J. Funct. Foods 2013, 5, 1732-1740. [CrossRef]

56. Corrêa, R.C.G.; De Souza, A.H.P.; Calhelha, R.C.; Barros, L.; Glamočlija, J.; Sokovic, M.; Peralta, R.M.; Bracht, A.; Ferreira, I.C. Bioactive formulations prepared from fruiting bodies and submerged culture mycelia of the Brazilian edible mushroom Pleurotus ostreatoroseus Singer. Food Funct. 2015, 6, 2155-2164. [CrossRef] [PubMed]

(C) 2020 by the authors. Licensee MDPI, Basel, Switzerland. This article is an open access article distributed under the terms and conditions of the Creative Commons Attribution (CC BY) license (http://creativecommons.org/licenses/by/4.0/). 